AÜIFD Cilt XLIV (20103) Sayı 2 s. 187-206

\title{
Ebioniteler'den Arius'a: Eskiçağ Doğu Hristiyanlığında İsa Teolojisi Tartışmaları
}

\section{Turhan Kaçar}

Yard. Doç. Dr., Balıkesir Üniversitesi

\begin{abstract}
From Ebionite to Arius: The Christolojik Controversies in the Ancient Eastern Christianity The nature of Christ became a constant matter of controversy in the early Christianity, especially from the second century to the fifth century. The reason behind it was the differing interpretation of the divine nature in Christ. Some argued that Christ was full God, God from God, on the other hand, some other Christian thinkers argued that the divine nature of Christ was bestowed on him later, and he was not fully equivalent of the God the Father. This article attempts to pursue the arguments and the historical developments of those who objected to the fully divine nature in Christ starting from the second century to the fourth century, when the theology of Christians became a concern for the Roman emperors.

Key Words: Ebionism, Third-century Christianity, Paulus of Samasota, Arianism, Christolojik Controversies.
\end{abstract}


M.S. 318-323 yılları arasında Alexandria'da (İskenderiye / Mısır) çıkan ve kısa süre içerisinde bütün Akdeniz kentlerinin Hristiyan cemaatleri arasında büyük kamplaşmalara neden olan Aryanist teoloji tartışmasının ilk evresinde, Arius'un teolojik olarak rakibi Alexandria Piskoposu Alexander, bütün kiliselere yazdığı bir genelgede, Aryanist teolojinin kökenini, Samsatlı Paulus (III. yüzyıl), Artemas (III. yüzyıl) ve Ebioniteler'e (II. yüzyıl) bağlamaktadır. Aryanizm, ilk Hristiyan Imparator Constantinus döneminde (306-337) Mısır'da, Hz. İsa'nın tabiatı (tanrısallığı ve beşerliği) üzerine tartışmalar neticesinde ortaya çıkmış ve etkileri sadece IV. yüzyılda değil, daha sonraki yüzyıllarda da görülebilen, geç antik çă̆ Hristiyanlı̆̆ının yaşadığı en ciddî bölünmedir. Bu bölünmenin baş müsebbibi olarak gösterilen Arius, Antiochia (bugün Antakya) kilisesinde eğitim almış bir Kuzey Afrikalıdır. Tek Tanrı'nın mutlaklığına vurgu yapan Arius, Hz. İsa'nın tanrısallığının ezelî-ebedî olmadığını, bilhassa bunun kendisine Baba Tanrı tarafından bahşedildiğini savunur.

Bu noktadan hareketle, bu yazının amacı, Aryanist teoloji tartışmasının erken devirlerdeki kökenlerini araştırmaktır. Zira Alexandria Piskoposu Alexander zaten böyle bir geleneğe işaret ediyor. Erken kilise yazarlarının verdiği bilgiler ve günümüz tarihçilerinin birinci ve ikinci yüzyıl Hristiyanlığına ilişkin yazılarından anlaşıldığı kadarıyla, Hz. İsa'nın tabiatı üzerine yapılan tartışmalar da III. yüzyılda birden ortaya çıkmış bir husus değildir. Çağdaş kaynaklardan ve bu konuya ilişkin modern çalışmalardan, II. yüzyılda ve öncesinde, $\mathrm{Hz}$. İsa'nın tabiatının, dönemin Hristiyanları arasında ciddi bir tartışma konusu olduğunu biliyoruz.' Hz.Ísa'nın tabiatının ilk defa ne zaman tanrisallaştırıldığını tam olarak tesbit etmek mümkün olmamakla birlikte, yaşadı̆̆ı dönemde onun tanrılaştırılmadığını söyleyebiliriz, çünkü izleyicilerinin ona 'öğretmen' diye hitap ettiklerini biliyoruz. ${ }^{2} \mathrm{Ne}$ varki, daha sonraki kuşaklarda ortaya çıkan, Hz. Isa'nın tabiatına farklı yaklaşımlar, bir yandan teoloji tartışmalarını alevlendirirken, bir yandan da ana kiliseyi resmî bir İsa anlayışı benimseme hususunda billurlaşmaya zorlamaktaydı. Kilise için en ciddî problem olan ve kaynaklarda ilk defa, muhtemelen I. yüzyılın ikinci yarısına tarihlenebilen, ancak reformasyon çağında bile kendisine taraftar bulan, ${ }^{3} \mathrm{~Hz}$. İsa'nın beşer

Bu çalışmamı değerlendirerek, beni pek çok yazım hatasından kurtaran Ilahiyat Fakültesi Dergisi'nin anonim hakemlerine kalpten teşekkür ederim. Elbette bütün muhtemel hataların sonumluluğu bana aittir.

' G.W.H. Lampe, "Christian Theology in the Patristic Period", in A History' of Christian Doctrine, ed. by H. Cunliffe-Jones, (Edinburgh 1997), 23-29.

2 Matta XXIII.8; ilk kuşak Hristiyanların Hz. İsa'ya yaklaşımlanı için ayrıca bkz. A. Harnack. The Expansion of Christianity in the First Three Centuries, 2. Cild, (Londra \& New York 1905) s. 1 vd.

${ }^{3}$ Michacl Servetus (1511-53), önce Protestanlar içinde yeralmasına rağmen daha sonra tcslisin yanlışığı üzcrinc yazdığı bir eserde (De Trinitatis Erroribus Libri VII). Hz. İsa'nın Tanrılığını reddedip, Logos'u da içerisinde barındıran (Logos'un ilâhî boyutu olması 
yönüne vurgu yapan bir teolojik akımın veya İsa teolojisinin (=kristoloji), ilk dört yüzyıldaki temsilcileri arasında nasıl bir gelenek zinciri vardı, ya da var miydi?

$\mathrm{Bu}$ konunun önündeki en büyük problem, kaynakların sadece dişardan olmasıdır. Gelenek sorununu, bu grupların dogrudan kendilerini anlatan dokümanları vasıtasıyla analiz etmek daha tatmin edici olabilirdi, ancak Katolik-Ortodoksluk ${ }^{4}$ tarafından sapkın olarak ilan edilen, farklı Isa anlayışına sahip olan grupların kendilerine ait metinlere çok fazla sahip değiliz. Hristiyan heretiklerin (dinî sapkın) yazılarının çok azının mevcut olması, bu noktada işimizi daha fazla zorlaştırmaktadır. Bu kaynak kıtlığının en önemli sebebi, o dönemde heretik olarak kategorileştirilen yazıların kasten imha edilmesidir ki, bu türün en iyi örneği, Arius'un yazılarının İmparator Constantinus tarafından yaktırılmasıdır. Buna ilaveten, pagan Roma İmparatorluğu'nun Hristiyanları takibatı sırasında kilise otoriteleri, "kutsal metinler" diye devlet yetkililerine heretik Hristiyanların metinlerini vermişlerdir." Esasen "tercih" anlamına gelen heretik terimi (Grekçe $\alpha \iota \rho \varepsilon \sigma(\zeta)$, çalışmamız içerisinde ana kilise dışında kalan Hıristiyanları adlandırmada kullanılacaktır.

\section{Yahudi Hristiyanlığı: Ebionitler, Theodotion ve Elkesaitler}

Hristiyanlık, Yahudi bir ortamda doğmuş ve Roma dünyasında uzunca bir süre Yahudiliğin içerisinde ortaya çıkan yeni bir mezhep olarak anlaşılmıştı; ancak pagan çevrelere intikal ederken önemli bir tartışmayı da doğurmuştu. Yeni din, pagan dünyaya takdim edilirken, ortaya çıktığı coğrafyanın renkleriyle mi yoksa yepyeni farklı bir karakterde mi sunulacaktı? Bu tartışma önce Yahudi âdetleri içerisinde önemli bir yer tutan erkeklerin sünnet edilmesi üzerine başladı. Hakikaten İncil'in Resullerin Işleri (15: 1-21) bölümünde verilen Kudüs toplantısının ana gündemi,

gerekmiyordu), ruh ve bedene sahip bir insan olarak cle ald. Servetus daha sonra John Calvin'in girişimleriyle engizisyona uğradı ve 27 Ekim 1553'de Champel'de (Cenova?) diri diri yakıldı. Bkz. The Oxford History of Christianity ed. by J. McManners, (Oxford 1993), s. 275; The Oxford Dictionary of the Christian Church ed. by F.L. Cross, (Londra 1958), 'Scrvetus' maddesi s. 1244.

"Hristiyanlığın ilk yüzyıllarında Katoliklik ve Ortodoksluk arasında her hangi bir ayrım olmadığını unutmamalıyız.

s Constantinus'un Heretiklere karşı tutumu ve bu konudaki fermanı için bkz. Eusebius VC, III.53-56; Arius'un yazılarına ilişkin İmparatorluk fermanı için bkz. Socrates, HE, I.9.3031.

'Optatus, Against the Donatists, I.15-19'da Carthago (Kartaca) piskoposu Mensurius'un, İmparator Diocletianus'un 303 yılında başlattığı büyük takibat sırasında, devlet yetkilileri kiliseyc ait kutsal metinlerin kendilerine teslimini talep ettikleri zaman, Hristiyan sapkınlann yazılarım teslim ettiğini yazmaktadır ki, böylesi durumların yaygın olduğunu düşünebiliriz.

${ }^{7}$ Herctiklik ve Ortodoksluk ilişkisi için bkz. W. Bauer, Ortodoksy and Heresy in Earliest Christianity (Mifflintown 1996) s. 130-32. 
Hristiyan olan Grek kökenlilerin sünnet edilip edilmeyecekleriydi. ${ }^{8}$ Çünkü Yahudilik içerisinde bir 'yenilenme' hareketi olarak doğan Hristiyanlık, aslında Yahudi geleneklerini de olduğu gibi miras alıyor ve devam ettiriyordu. Kitab-l Mukaddes'in 'Eski' ve 'Yeni Ahid' olarak bölünmesi bunun en somut göstergesidir. Eskiçağ'da anti-semitizmin (Yahudi düşmanlığı) önemli nedenlerinden birisi olan erkek çocuklarının sünnet edilmesi, Yahudilerin çevresinde yaşayan pagan dünyada çok tepki gören bir uygulamayd $1{ }^{9}$ Kendisi iyi eğitimli bir Yahudi ve esasen havari de olmayan Aziz Paulus," Hristiyanlığı Anadolu'ya tanıtırken, bu sünnet meselesi yeniden problem oldu. Oda, Grek dünyasında Hristiyanlığı yayabilmek için, Yahudi hukukundan vazgeçilmesi ve bağımsız yeni bir Hristiyan geleneği oluşturulması gerektiğini savunmaya başladı. ${ }^{11} \mathrm{Bu}$ düşüncesine paralel olarak Kudüs toplantısında sünnet aleyhine bir tavır takınarak, yeni bir gelenek hususundaki görüşünü kabul ettirdi. Fakat Kudüs'te kalan esas Hristiyan çekirdek ise Yahudi değerlerin muhafazasını savunuyordu, çünkü $\mathrm{Hz}$. İsa esasen Yahudi geleneklerinin bir 'yenileyicisi' olarak gelmişti. Pratik âdetlerden başlayan bu ayrılık tartışması, zamanla ilahiyat boyutuna da kaymış olmalıdır, hakikaten Ebionite veya 'Yahudi Hrıstiyanlığı' olarak adlandırılan grup, Paulus'u Yasa'dan ayrıldığı için gerçek havari olarak kabul etmiyordu. ${ }^{12}$

"Yahudi Hristiyanlığı" kavramı Kilise literatüründe dört grup olarak tasnif edilmektedir: 1- Yahudi olarak doğmuş, fakat Mesih'e inanarak Hristiyan Kilisenin ilk çekirdeğini oluşturanlar; 2- Tevrat'ın emirlerini esas kabul edip, İsa inancını da buna dâhil eden legalist Yahudiler; bunlar kendilerini orijinal ve yasal Hrıstiyanlık olarak kabul ederken, pagan Hıristiyanlığını 'Hellenistik' veya 'Paulusçu' olarak tanımlarlar; 3-Yahudi apokaliptik düşüncesini Hristiyan çevreye uyduran eklektik Hristiyanlık; ancak bunlar çok belirli bir gruba dâhil edilmiyor. 4- M.s. II. yüzyılda hem Katolik kilisenin hem de 'Ortodoks sinagogun' dışında kalan dolayısıyla bir

${ }^{8}$ Karş. Galatyalılara Mektup, 2:1-10, aynı metnin özellikle 3. bölümü Paulus'un Musa yasalan hakkındaki görüşlerini veriyor

9 Yahudilerde sünnet sorunu ve eskiçağlı toplumların bu uygulaınaya yaklaşımı için bk7.. P. Schäfer, Judeophobia, Attitudes toward the Jews in the Ancient World, (Londra \& Massachusets 1997), s. 93-106.

${ }^{10}$ Havariliğin kriteri için bkz. aşağıda not 12.

"Galatyalllara Meklup 3, 4; E.P. Sanders, Paul, the Law, and the Jewish People, (SCM Press: Londra 1983), s. 17-27; C. Rowland, Christian Origins, An Account of the Setting and Character of the most Important Messianic Sect of Judaism, (Londra 1985), s.220-222. A.N. Wilson, Paul, The Mind of the Apostle, (Londra 1997) s.128-33.

${ }^{12}$ Hristiyan inanışına göre, Hz. İsa, çarmıha gerilişinin üçüncü gününde geri döndüğü zaman, bu olaya tanık olanlar arasında Paulus yoktu ve onun için de Havari sıfaı kazanamamıştır. ancak Paulus kendi kendini Havari olarak tanımlamaktadır. Galatyalılara Mektup, 1: 15-16; Irenaeus, Against Heresies, 1.26.2.; W.H.C. Frend, The Rise of Christianity, (Philedelphia 1984) s. 91-95, Paulus'un bir Hristiyan olarak ortaya çıkışını tartışıyor. Ayrıca bk7. Rowland, a.g.c. 215-220. 
ortak nokta edinen dinî gruplar. ${ }^{13}$ Bütün bunların ortak noktası, İsa inancının bir şekilde genel inanç tanımlaması içerisine entegre edilmesidir. Dördüncü tanıma uyan dinî gruplar Katolik kilise tarafından genel olarak 'heretik', 'vejetaryen', 'Gnostik' veya 'senkretik' olarak nitelenmektedir. Katolik kilise, her ne kadar bu sıfatları heretiklerin genel özellikleri olarak sunarsa da, bunların her bir grup için tam olarak geçerli olmadığını belirtmeliyiz. Ebioniteler, Cerinthus ve Symmachius taraftarları, Elkesaitler, bu grupların I. ve II. yüzyıldaki ilk örneklerini oluştururlar. Bunlara ilaveten II. yüzyıl sonlarında ortaya çıkan ve gelecek yüzyıla kadar var olan bazı düşünce akımları da vardır ki, bunlar monarşistler olarak bilinir. Monarşistler, dinamik ve şeklî (modalist) olmak üzere iki grup altında değerlendilmektedir ki, aşağıda bu konu daha detaylı olarak incelenecektir.

Genellikle, Yahudi-Hristiyanlığının vücuda geldiği dini grup olarak teşhis edilen Ebioniteler hakkında bildiklerimiz ne yazık ki içerden değil, dışardan yani onları "heretik" olarak sunan Hristiyan yazarların kaleminden çıkan yazılardır. Bu grubun "Ebion" isimli bir liderden" ${ }^{14}$ dolayı mı böyle anıldığ 1 , yoksa "yoksul" anlamına gelen Aramice ebion teriminden mi geldiği tartışma konusu olmakla birlikte; Eusebius, ebion sıfatının, bu gruba $\mathrm{Hz}$. İsa' yı Tanrı olarak tanımayıp, beşer olarak kabul ettikleri için verildiğini yazar. ${ }^{15}$ Hakikaten terim İncil'de de bu anlamda kullanılmıştır. Hristiyanlığı, Yahudi çevreden bağımsızlaştırarak Grek çevrelere adapte eden Paulus, kendisine Kudüs'teki 'yoksullar' için bağı̧s toplaması buyurulduğunu yazar. ${ }^{16} \mathrm{Bu}$ ibare Kudüs'teki ilk Hristiyan cemaatin bu terimle anıldığını da düşündürtmektedir. Erken kilise literatüründe, Ebioniteler'den bahseden Irenaeus, Hippolytus, Tertullianus, Origenes, Eusebius ve Epiphanius gibi yazarların tamamının ortak özelliği, ortodoks çizgide yeralmaları ve Ebioniteler'i heretik halka içerisinde görmeleridir. Bu yazarlardan Irenaeus'un Ebioniteler hakkında verdiği bilgiler çerçevesinde -ki bunlar Origenes tarafından da onaylanmaktadır- bu grubu, diğerlerinden ayıran

${ }^{13}$ Bu konuda daha geniş bir değcrlendirme için bkz. Georg Strecker, "On the Problem of Jewish Christianity", Bauer, a.g.e. (içinde) s. 241-85; Glenn A. Koch "Jewish Christianity" E. Ferguson, Encyclopedia of Early Christianity, (New York \& Londra 1998), s.613-16.

${ }^{14}$ Hippolytus, The Refutation of All Heresies 7.22; Tertullianus, Ebion'u Cerinthus'un halefi olarak niteler fakat onun bütün görüşlerini de paylaşmadığın belirtir. Bkz. Tertullian, Against All Heresies, 3 (appendix), (ANF, c.III, s. 651) ayrıca bkz. Tertullian, Prescription Against Heretics 33 (ANF c.III, s.259). Ebion, Hebion olarak veriliyor. Epiphanius Panarion 30.1.1. Ebion'un bu yazarlar tarafından bir kurucu figür olarak nitelenmesi, bu grubu diğer (heretik) Hristiyan gruplara bağlama kaygısının sonucudur ki, yukarıdaki yazarlar sürekli böylesi bir devamlılığı da vurgulamaktan geri kalmazlar.

"15 Euscbius, HE, III.27.1-2; G. Strecker, "On the Problem of Jewish Christianity", Bauer a.g.c. (içinde) s. $272 \mathrm{vd}$; Judith Lieu, "History and Theology in Christian vicws of Judaism" The Jews Among Pagans and Christians in the Roman Empire, cd. by J. Lieu, J. North, \& T. Rajak. (Routledge: Londra 1992), (içinde) s. 89-90; H.J. Schoeps, "Ebionite Christianity", Journal of Theological Studies IV (yeni seri), 1953: 219-224;

"Galatyalilara Mektup, 2.10. 
noktaları şöyle sıralayabiliriz: Ebioniteler Paulus'un havariliğini ve mektuplarının geçerliliğini reddederler; sadece Matta İncilini temel alırlar; Kudüs'e hürmet ederler ve erkeklerin sünnet edilmesi geleneğini izlerler; $\mathrm{Hz}$. İsa'yı Yahudi geleneği çerçevesinde bir peygamber olarak benimsemekle birlikte, bazıları Hz. İsa'nın bakire bir anneden doğduğunu kabul ederken bir kısmı kabul etmez; ${ }^{17} \mathrm{~Hz}$. İsa'nın son akşam yemeği üzerine düzenlenen törende, şarap yerine sadece su kullanırlar. ${ }^{18}$ Epiphanius, Ebionite literatürü hakkında bilgi verirken bu grubun kendi İncil'ine sahip olduğunu (Ebionite Incil) belirterek bundan alıntılar yapar. ${ }^{19}$ Anlaşılan o ki, Ebioniteler veya yazıları IV. yüzyıl sonlarında hâlâ mevcudiyetlerini muhafaza ediyorlardı. Hemen hemen bütün ortodoks yazarların ortak kanaati, Ebionite'lerin "radikal Hristiyanlar" oldukları şeklindedir.

Eski Ahid'i Grekçeye çeviren isim olarak bilinen Theodotion hakkında kesin olarak bilinen çok fazla bir şey yoktur. II. yüzyılın sonlarında yazan Aziz Irenaeus, çağdaşı Theodotion'dan bir Yahudi dönme olarak bahsederken, ${ }^{20}$ dördüncü yüzyılda Aziz Jerome (Eusebius Hieronymus) onu bir Ebionite Hristiyann ${ }^{21}$ ve yine aynı yüzyılda yazan Salamis (Kıbrıs) Piskoposu Epiphanius, Theodotion'u Marcion'un izleyicisi olarak sunar. ${ }^{22}$ Kilise tarihçisi Eusebius ise, Theodotion'un sadece ismini anar ve Origenes'in Eski Ahid incelemesinde Theodotion'un çevirisini de kullandığını not eder. ${ }^{23}$ Theodotion ile ilgili sahip olduğumuz bilgilerde iki nokta dikkat çekmektedir; birincisi onun Ebionite kimliği ve ikincisi Yahudilikle olan ilişkisidir. Dolayısıyla burdan itibaren temel sorun, Ebioniteler'in $\mathrm{Hz}$. İsa'yı nasıl algıladıkları ve bizim bunu nasıl bir çerçeveye yerleştireceğimizdir.

IV. yüzyıl Hristiyan yazarlardan Epiphanius, Ebioniteler'in bir başka kolunun da Elkesaitler olduğunu yazar. ${ }^{24}$ Kuşkusuz kendisinden iki yüzyıl önce Mezopotamya'da ortaya çıkmış olan bu grup hakkında, heretiklere

${ }^{17}$ Origenes, Ebioniteler içerisinde bazılarının bakire doğumu kabul ettiklerini yazar. Origen, Against Celsus 2.1; On the First Principles 4.3.8; ayrica bkz. J.N.D. Kelly, Early Christian Doctrines. (Londra 1985) s.139 vd.

${ }^{18}$ Irenaeus, Against Heresies, V.1.3.

${ }^{19}$ Epiphanius, Panarion, 30.1-34; G. Howard. "The Gospel of the Ebionites" ANRW 1988. 2.25.5, s. 4034-4053.

${ }^{20}$ Irenacus, Against Heresies, III.21.1.

${ }^{21}$ Jerome, The Lives of Illistrous Men, 54.

${ }^{22}$ Epiphanius, Panarion 54.1 vd. Epiphanius'un iddiası gerçeği yansıtmamaktadır, çünkü diğerlerinin Theodotion hakkında söyledikleri birbirlerini tamamlarken Epiphanius bunların tamamen dışında kalmıştır. Zira önde gelen Gnostik hocalardan olan Sinoplu Marcion, Yahudi olmadığı gibi Yahudiliğe de şiddetle karşı çıkan bir kişidir. Tertullian, Against All Heresies (Appendix IX), 8; Kelly, Doctrines, s. 57 vd.

${ }^{23}$ Eusebius, $H E$, VI.16.1, 4 .

${ }^{24}$ Epiphanius, Panarion, 19'da Elkesaitleri 'Ossaeans' ve Panarion 53'de ise 'Sampscans'adı altında ele alır ve bu tarikatın ilk İmparator Traianus devrinde (ı.s. 98-117) ortaya çıktığını belinterek Ebioniteler ile ilişkisini not eder. 
karşı aşırı önyargılı Epiphanius'un yazdıklarının doğruluğunu test etmek güç görünse de, Elkesaitlere ait bir metin olan Elkesai Kitabl sünneti, şabata uymayı. ibadet esnasında yönün Kudüs'e dönük olmasını ve özellikle yeni bir vaftizi emrediyordu. Elkesaitlere kurbanı yasaklayan bu kitap, Tanrı'nın Oğlu (Hz. İsa); ve Kutsal Ruh'a özel vurgu yapıyordu. ${ }^{25}$ M.S. III. yüzyılda Roma'da yaşamış olan papaz Hippolytus, Apamea'lı Alcibiades'ín erken III. yüzyılda Roma'ya geldiğini ve Elkesai Kitabı temelinde ikinci bir vaftizi vaaz ettiğini yazar ${ }^{26}$ Keza ilk kilise tarihçisi Caesarealı (Filistin) Eusebius da, Origenes'in Elkesaitlerin erken III. yüzyılda Caesarea'ya geldiğini yazdığına atıfta bulunur. ${ }^{27}$ Ortaçağ'da İbn Nedim tarafından yazılan Arapça Fihrist'de, Manikeizmin (veya Manesçilik) kurucusu olan Manes'in, Elkesaitlerin bir mensubu olduğu belirtilmektedir. ${ }^{28} \mathrm{Keza}$, son zamanlarda bulunan ve Köln Manes Kodeksi diye adlandırılan doküman, Manes ile Elkesaitler arasındaki bağlantıya dikkat çekmektedir. ${ }^{29}$ Bu kodeks sadece Manes hakkında değil, fakat Elkesaitlerin organizasyonu, ritüelleri ve teolojileri üzerine de bilgi vermektedir. Bu noktaya kadar ortaya çıkan sonuç, II. ve III. yüzyıllarda Mezepotamya'da çıkan Elkesaitler'in de, Yahudi-Hristiyanlığı akımının bir kolu olduğudur.

\section{Theodotus'dan Samsatlı Paulus'a Monarkhia Tartışması}

Grekçe bir terim olan monarkhia, siyasal bilimlerde "bir kişinin mutlak yönetimini" ifade etmek için kullanılırken, Hristiyan ilahiyatında da "Bir'in (Tek bir Tanrı'nın) mutlak hâkimiyeti" anlamına gelir. İlk yazarlar içerisinde, $\mathrm{Hz}$. İsa' yı açıkça Tanrı olarak ananlar olduğu gibi, ${ }^{30}$ onu bilgelik ve irfan sahibi olarak görüp, ilâhî tabiatını reddetmemekle birlikte, Baba Tanrı'dan farklı bir kimliği olduğunu söyleyenler de vardır. ${ }^{31}$ İşte bu noktada, "monarkhia savunucuları" (=bundan sonra monarşistler olarak anılacaktır) diye bilinen bir teoloji akımı, bu iki görüş arasında bir orta yol bulmaya çalışmaktaydı. XIX. Yüzyılın sonunda ünlü Alman kilise tarihçisi

${ }^{25}$ Eusebius, HE, VI.38; J. Irmscher, "The Book of Elkesai" The New Testament Apocrypha ed. by W. Schneemelcher (^ng. Çev. ve edisyon R. Wilson) 2 cilt, (Louisvillc 1991-92) (içinde), II cilt, s. 685-90.

${ }^{26}$ Hippolytus, The Refutation of All Heresies, IX.10-12; X.25.

${ }^{27}$ Eusebius, $H E$, VI.38.

28 The Fihrist of al-Nadim, (Ingilizce edisyon ve çeviri B. Dodge), (New York 1970), s. 745 825.

"Ellen Bradshaw Aitken, "The Cologne Mani Codex" Religions of Late Antiquity in Practice (içinde) (ed.) R. Valantasis, (Princeton \& Oxford 2000), s. 161-176.

${ }^{30}$ Eusebius, $H E$, V.28.5' de Melito'nun, $\mathrm{Hz}$. İsa' yı 'Tanrı' ve 'insan' olarak öğrettiğini yazar. Meselâ Antiochia piskoposu Ignatius, İmparatorluk yctkilileri tarafindan Roma'ya götürülürken. Ege bölgesindeki (Roma'nın Asia eyaleti) altı kiliseye yazdığı mektuplarda hem tcolojisini açıklar hem de otoriter kilise yapısını destekler. Ignatius'un mektupları için bkz. The Apostolic Fathers, şurada: ANF c.I. (Edinburgh 1996) s. 45-97.

${ }^{31}$ Justin. Dialogue with Trypho 126, 136; Hippolytus, Treatise on Christ and Antichrist, ANF V, s.204-19). 
Adolf von Harnack monarşistleri savundukları farklı İsa-teolojisine binaen iki gruba ayırmıştır. Harnack, Hz. İsa'nın aslında bir bedeni olmadı̆̆ını savunanları şekilci monarşistler; Hz. İsa'nın aslında sadece bir insan olduğunu fakat sonradan ilâhî niteliklerin kendisine verildiğini savunanları da dinamik monarşistler olarak adlandırmaktadır ${ }^{32}$ Şekilci monarşizmin görüşüne, göre tek bir ilâhî varlık kendini 'Baba' 'Oğul' ve 'Kutsal Ruh' olarak göstermişti ve teslis diye de bilinen bu üçlü isim ilâhî aktivitenin geçici biçiminden başka bir şey değildi. Bu teoloji, ilk kez Smyrnalı (İzmir) Noetus tarafından savunulmaya başlanmış ve buradan Roma'ya taşınmıştı. Noetus 190 yılı civarında Smyrna'da aforoz edildi; fakat öğretisi, öğrencisi Epigonus ve onun öğrencisi Cleomenes tarafından devam ettirildi. ${ }^{33} \mathrm{Bu}$ teolojinin kutsal metinlerdeki referans noktast $\dot{I}_{\text {şaya }}$ 45:14 ve Yuhanna 10:30 idi. ${ }^{34}$ Yukarıda adı geçen üç ilahiyatçıya göre; Hz. İsa, kendisini görenlere sadece 'Oğul' idi, ama kendisini algılayabilenlere ise, 'Baba' olduğu gerçeğini de gizlemedi.

Monarşi savunucuları arasında bir grup daha vardı ki, onlar inanç olarak Ebioniteler'e çok benzemekteydiler. Dinamik monarşizm (Grekçe $\delta v v \alpha \mu \varsigma / d y n a m i s ;$ güç, iktidar anlamına gelmektedir) olarak anılan bu grubun tespit edilebilen kökeni, deri tüccarı Theodotus ile başlayıp Samsatlı Paulus'tan Arius'a ve dahası 357 yılında yazılan Sirmium (bugün eski Yugoslavya'da Mitroviça) itikadının (credo) yazarı Aetius'a ve bu teolojinin dördüncü yüzyıldaki son büyük temsilcisi Eunomius'a kadar uzanmaktadır. $\mathrm{Bu}$ düşünce akımının İsa teolojisi de monoteistik idi. Buna göre $\mathrm{Hz}$. İsa, Tanrı'nın tecessüm etmiş şekli olmayıp, ilâhî gücü Tek Tanrı'dan almış bir insan idi. ${ }^{35}$

Dinamik monarkhia teolojisinin bilinen ilk savunucusu Byzantiumlu bir deri tüccarı olan Theodotus, 190'lı yıllarda Roma'da öğretisini Luka İncili

${ }^{32}$ Harnack'ın 1899'da Berlin Üniversitesi'nde verdiği dersler daha sonra kitaplaştırılarak İngilizceye çevrildi. A. Harnack, What is Christianity («ng. çev. T. Bailey Saunders) (4. bask1), (New York 1923), bkz. özellikle s. 107 vd; A. Harnack, Expansion of Christianity in the First Three Centuries, cilt I. (İng. çev. J. Moffat), (New York 1904), s. 282 vd, ayrıca bkz. R. Lymna "Monarchianizm" Ferguson, a.g.e. (içinde) s. 764-66; Kelly, Doctrines, s. 115-119. Lampe. a.g.c. s. 23-29 ve 85-98.

${ }^{33}$ Hippolytus, The Refutation of All Heresies, IX.2, X.23; idem, Against The Heresy of One Noetus, ANF cilt V, s. 223-231; Epiphanius Panarion 57.1.1'de Noetus'un III. yüzyilın ortalarında yaşadığını yazarsa da bu kronoloji doğru değildir, çünkü Epiphanius sadece Noetus hakkında yazarken değil Montanistler üzerine yazarken de aynı kronoloji yanlışlığına düşmektedir.

${ }^{4}$ işaya 45:14 “...ve senin önünde yere kapanacaklar ve, sana yalvarıp diyecekler: Gerçek Allah sende, ve başkası, başka Allah yok"; Yuhanna 10:30 "Ben ve Baba biriz".

${ }^{35}$ Kelly, a.g.e., 280 vd; Lampe a.g.e., 121-148; R.P.C. Hanson, The Search for the Christian Doctrine of the God, (Edinburgh 1988), s. 617-36. IV yuzyll kilisesinde doktrin tarışmalarına ilişkin yararlı bir çeviri için bkz. Karen Armstrong, Tanrı'nu Tarihi, Ibrahim'den Günümüze 4000 Yıllık Tanrı Arayışt (çev. O Özel, H. Koyukan \& K. Emiroğlu) (Ayraç: Ankara 1999) s. 151 vd. 
1.35 'e ve Kutsal Metinlerde $\mathrm{Hz}$. İsa'nın beşer yönüne vurgu yapan ayetlere göre yorumluyordu. ${ }^{36}$ Çağdaşı Hristiyan yazarlara göre, Theodotus, İsa'nın ilâhî gücü vaftizi esnasında aldığını savunuyordu ${ }^{37}$ Theodotus'un Roma Piskoposu Victor (189-98) tarafından aforoz edildiğini biliyoruz ancak sonraki kaderi hakkında bilgimiz yoktur. ${ }^{38}$ Onun öğretisi, banker olan öğrencisi bir başka Theodotus tarafından devam ettirildi. Bu Theodotus, $\mathrm{Hz}$. İsa'yı, Tanrı ile beşer arasında aracı olan yeni bir Melchizedek ${ }^{39}$ olarak tasvir ediyordu. ${ }^{40} \mathrm{Bu}$ teolojinin III. yüzyılın ortalarında bir başka öğretici tarafından devam ettirildiğini görüyoruz. III. yüzyılın ilk yarısının sonlarına doğru Roma'da olduğundan başka, hakkında ne yazık ki hiç bir şey bilmediğimiz Artemon (veya Artemas), kendinden önce gelen iki Theodotus'un öğretilerini biraz daha geliştirmiştir. Hz. İsa'nın beşer, ancak üstün bir beşer olduğunu savunan Artemon, adoptionizm ${ }^{4 \prime}$ olarak bilinen bu öğretisinin, hakiki apostolik gelenek olduğunu düşünüyordu. Artemon'a göre, kilise bu hakiki apostolik geleneği, Logos teolojisini benimsedig̨i için terketmişti. ${ }^{42}$ Logos teolojisi, Yuhanna Incili'nin girişinde Tanrı ile Logos (Söz veya Kelam) arasındaki ilişkiyi benimseyen ve bunu formüleştirerek İsa'nın ezelî ve ebedî olduğunu savunan teolojidir. ${ }^{43} \mathrm{Bu}$ teoloji çerçevesinde çizilen Nicaea (bugün İznik) konsilinin itikad metni de Tanrı ile İsa'nın öncesiz ve sonsuz birlikteliğini vurgular. ${ }^{44}$

${ }^{36}$ Luka 1.35 "Melck ona şöyle cevap verdi: 'Kutsal Ruh senin üzerinc gelecek, en yüce olanın gücü senin üstüne gölge salacak. Bunun için doğacak olana kutsal, Tann Oğlu denecck"; Yuhanna 8:40 "Ama şimdi beni -Tanrı'dan işittiği gerçeği sizlere bildireni- öldürmek istiyorsunuz" aynca karş. Matta 12:31 vd; Resullerin Işleri 2:22; Timoteyus'a I. Mektup,

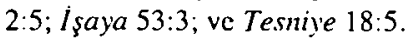

${ }^{37}$ Hippolytus. The Refutation of All Heresies, VII.23.

${ }^{38}$ Hippolytus, The Refutation of All Heresies, VII.23, X.19.

${ }^{39}$ Kudüs'ün Kenanlı kralı, sünnetsiz toplumlardan bir din adamı. Tevratın Genesis bölümü (Tekvin) 14: 18-20. Hz. İsa genellikle onunla karşılaştırılır. Ibranilere Mektup 5:1-10; 7:3. Hristiyanlar Melkiscdek'i insan olarak düşünür, fakat Qumran yazıları onu cennetten gelme birisi olarak sunarlar.

4) Hippolytus. The Refutution of All Heresies, VII.24.

${ }^{4} \mathrm{Bu}$ teoloji $\mathrm{Hz}$. Isa'yı ilâhî güçlerle donatılmış (Baba Tanrı tarafından sonradan evlat edinilmiş) marifetli bir beşer olarak algılar.

${ }^{42}$ Eusebius, HE. V.28.3.

${ }^{43}$ Yuhanna 1:1-3 "Başlangıçı Söz vardı. Söz. Tanrı'yla birlikteydi (veya Tanrı'daydı) ve Söz Tanrı'ydı. Başlangıçta $O$, Tanrı'yla birlikteydi. Her şey O'nun aracılığıyla varoldu, var olan hiç bir şey O'nsuz. olmadı".

4 “...Tanrı'nın Oğlu, Baba'nın cevherinden, Tanrı'dan Tanrı; Işık’dan Işık, Oğul edinildi ama yaratılmadı" Nicaea itikadının metni için bkz. Caesarea piskoposu Eusebius'un kendis kilisesine yazdığı mektup Socrates, $H E$, I.8; Theodoret, $H E$, I.12; Opitz, Urkunde 22 (=H.G. Opitz, Urkunden zur Geschichte des Arianischen Streites 318-28, (Bcrlin 1934); E.J. Jonkers, Acta et Symbola Conciliorum quae saeculo quarto habita sunt, (Leiden 1954), s.38-9; H. Percival. The Seven Ecumenical Council of the Undivided Church, (Edinburgh 1997).s.3. 


\section{Samsatlı Paulus}

Artemon'dan sonra onun İsa-teolojisini devam ettiren, doğu Hristiyanlığının en önemli iki merkezinden biri olan Antiochia piskoposluğunu elinde tutan Samsatlı Paulus'dur. Paulus'un hayatıyla ilgili sağlam bir kronoloji çıkarmak şu an için mümkün görünmemektedir. Fakat Paulus, Antiochia piskoposluğuna muhtemelen 260 'dan sonra selefi Demetrianus'un Persler tarafından şehirden götürülmesi üzerine getirildi. 260 'lı yıllarda kentin yaşadığı siyasal değişim deneyimlerinin Paulus'un hareketlerinde ne kadar etkili olduğunu tespit etmek kolay değildir. Antiochia 261 'de Perslerin eline geçti, fakat kısa bir süre sonra kent Palmyra Kraliçesi Zenobia tarafından Perslerin elinden alınarak yeniden Roma taraftarı bir yönetim oluşturuldu. Ancak, Roma İmparatorluğu'nda iç savaşlardan yararlanmak isteyen Zenobia, 260'lı yılların sonunda (269 veya 270) bağımsızlığını ilan ederek bir süre Antiochia'yı işgal etti, ancak 270'li yılların hemen başında Aurelianus'un duruma hâkim olmasıyla Antiochia tekrar bütünüyle Roma kontrolü altına girdi. ${ }^{45}$

Paulus ile ilgili en geniş bilgi bulmayı ümid edeceğimiz, Caesarea'lı Eusebius'un Kilise Tarihi ne yazık ki bu konuda çok aydınlatıcı değildir. Eusebius'un muhafaza ettiği bir mektuba dayanarak verdiği bilgilerde Paulus'un çok negatif bir portresi çizilmektedir. Bunun sebebi açıktır; mektup Paulus'un hasımlarının yazdığı bir dokümandır ve bu hasımlar Paulus'u aforoz etmiş olmarına rağmen görevden uzaklaştıramamışlardır. Eusebius'un kendi yaşadığı döneme (260-339) çok yakın olan Paulus'un teolojisi hakkında hemen hemen hiç konuşmaması, tarihçinin kilise içi genel eğilime ters düşen teolojileri gizlemek istemesinden kaynaklanmaktadır. Eusebius'un 260'lı yıllarda Paulus'u Antiochia piskoposluğundan düşürmek için toplanan sinodları hatırlaması mümkün görünmemekle birlikte, kendisinden bir kaç yaş büyük çağdaşları (en azından hocası Pamphilius) bu sinodu ve Paulus'un ilahiyat anlayışına çok vâkıf olmalıydı. ${ }^{46}$ Ancak bunun yerine Eusebius, Paulus ile ilgili bilgileri, erken kilisede piskoposların konsillerinde aforoz ettikleri rakipleri hakkında yaptıkları ahlâkî zaafiyet suçlaması ile geçiştirmektedir. ${ }^{47}$ Onun için, teolojisi hakkında çok fazla detaya sahip olmadığımız Paulus'a, yöneltilen suçlamaların doğruluğunu kabul etmek mümkün değildir, çünkü Paulus'un izleyicileri Nicaea konsili

${ }^{45}$ Roma İmparatorluğu'ndaki III. yüzyıl krizi ve bunun dış politikadaki yansımaları, RomaPalmyra ilişkileri için bkz. F. Millar, The Roman Near East 31 BC-AD 337, (Harvard University Press: Londra 1993) s.159-173; G.M. Rogers, "The Crisis of the Third Century AD." Belleten 52/205, 1988: 1509-26.

${ }^{40}$ Eusebius'un kendi kenti Cacsarea'nın o zamanki piskoposu Theotecnus'un, Paulus'a karşı düzenlenen toplantılara katıldığı, konsilin nihai genelgesinde yazılıdır. Bkz. Euebius, $H E$, VII.30.2, karş. $H E$, VII.28.1.

${ }^{47}$ Socrates, $H E, 1.24 .1-2$ 'de konsillerde toplanan kilise liderlerinin azl veya aforoz ettikleri rakiplerini âdeta bir gelenekmiş gibi ahlâkî karekter zaafiyetiyle suçladıkları tesbitini yapar. 
sonrasına kadar kentte hâlâ etkin bir cemaat kurabilmişlerdi. ${ }^{48}$ Şayet Paulus’a izafe edilen suçlamalar doğru olsaydı kendisi öldükten sonra da hâlâ taraftar bulması pek mümkün olmazdı.

Eusebius'a göre, Paulus'un İsa-teolojisi, devrin ortodoksluk anlayışına ters düştüğui için kısa sürede Antiochia kilisesi 264-68/9 yılları arasında, Paulus'u görevden uzaklaştırmak veya yeniden yaygın anlayışa entegre etmek için, çevre eyaletlerin önde gelen piskoposlarının katıldığı üç ayrı sinoda tanık oldu. ${ }^{49}$ Illk iki toplantı Caesarea (bugün Kayseri) Piskoposu Firmilianus tarafından yönetilir. Bize ulaşan kayıtlara göre kilise meclisi ilk iki toplantıda Paulus'u katolikliğe yeniden entegre eder, ancak her defasında tekrar kopma meydana gelir. Aslında Eusebius'un verdiği bu bilgiyi, biraz tersinden okuyup, ilk iki toplantıda piskoposların, Paulus ile girdikleri tartışmalarda, teolojik olarak onu ikna edemedikleri veya Paulus'un teolojisine yeteri kadar karşı koyamadıkları şeklinde bir spekülasyon yapabiliriz, çünkü üçüncü toplantıya, sadece piskoposları değil özellikle tartı̧̧macı olması için Antiochia kentinin retorik hocası Malchionu çağırırlar. Malchion ile Paulus'un tartışmasından bazı fragmanlar mevcut olmakla birlikte, bu fragmanlardan tartışmayı teolojik olarak hangisinin kazandığını tesbit etmek mümkün değil; ama üçüncü sinod neticesinde yazılan genelge mektupta, tartışmada Malchion'un en azından politik olarak Paulus'a üstün geldiği yazılıdır. Ancak burada da bazı şüpheler vardır: Birincisi, mektubu yazan zaten Malchion'un kendisidir. ${ }^{50}$ Ikincisi, mektup Paulus'u ducenarius olarak niteler $\mathrm{ki}^{\mathrm{s}}{ }^{\mathrm{I}}$ bu ünvan hem Roma askeri bürokrasisinde hem de Palmyra krallığında -Romalılardan alınma- kullanılır. Paulus'un Roma'ya ait bir ducenarius mu yoksa Palmyra bürokrasisi saflarında mı olduğunu şu an için bilmiyoruz. Ancak Paulus Palmyra safında ise, bu niteleme onu aynı zamanda Antiochia'y1 Zenobia'dan geri alan İmparator Aurelianus'a ihbar amacı güdebilir. ${ }^{52}$ Üçüncüsü ve belki de daha önemlisi, Malchion'un kaleme aldığı mektup, tartışma ve Paulus'un teolojik görüşleri hakkında hemen hiç

47 Nicaea konsili kanon (yasa) 19; bu kanonun yorumu için bkz. F. Loofs, Paulus von Samosata, Eine Untersuchung zur Altkirchlichen Literatur und Dogmengeschichte, (Leipzig 1924) 164-180; konsilin 19. yasası için bkz. Jonkers, a.g.e. s. 46-47; Percival, a.g.e. s. $40-42$.

${ }^{49}$ Bu sinodlara ilişkin en son çalışma için bkz. J.A. Fischer, "Die antiochenischen Synoden gegen Paul von Samosata" Annuarium historice conciliorum 18, 1986: 9-30.

s) Jerome, Lives of lllustrious Men, 71.

${ }^{\text {sl }}$ Paulus üzerine yazılmış modern literatürü cle alan ve Paulus-Zenobia ilişkisini savunan bir çalışma için bk7. F.W. Norris, "Paul of Samosata: Procurator Ducenarius" The Journal of Theological Studies (yeni seri) 35/1, 1984: 50-70.

${ }^{52}$ Loofs, a.g.e. s. 20-34; F. Millar, "Paul of Samosata, Zenobia and Aurelian: The Church, Local Culture and Political Allegiance in the Third Century Syria" Journal of Roman Studies 61, 1971: 1-17, Paulus ve Zenobia arasındaki yakınlığı reddeder. 
bir bilgi vermemektedir ki, bu çok tabii bir durum değildir. ${ }^{53}$ Zira böylesi durumlarda mektuplar sadece propaganda amaçlı değil, ama aynı zamanda bilgilendirme işlevine de sahiptir. ${ }^{54}$

Paulus'un teolojisi hakkında bizi aydınlatması gereken sinodun genelge olarak yayınladığı mektup, bu konuda bir şey söylememektedir. Buna rağmen, bir şekilde bize ulaşan fragmanlardan, onun kendisinden önceki Artemon gibi, Hz. İsa'nın ezelî ve ebedî olarak Tanrı kabul edilmesini onaylamadığını tespit edebiliyoruz. ${ }^{55}$ Mevcut fragmanlara göre Paulus, Malchion ile tartışması esnasında Hz. İsa'nın ilâhî ve beşerî tabiatı arasındaki ilişkiyi şöyle izah etmektedir:

"Beşer olan İsa mesh edilmiştir (takdis edilmiştir), Söz takdis edilmemiştir. Nasıralı, bizim Efendimiz takdis edilmiştir... Meryem, Söz doğurmadı çünkü o, çağlar öncesi değildir. Meryem, Söz'ü aldı ve Söz'den daha eski değildir; fakat o, bizim gibi bir insan doğurdu ki, o her bakımdan bizden daha iyidir, çünkü Kutsal Ruh vasitasıyla gelen inayet ondadır." 56

Bu fragmanın sahih, yani sözlerin doğrudan Paulus'a ait olduğunu kabul edersek, ulaşacağımız sonuç şudur: Paulus, Hz. İsa'nın tecessüm etmiş bir Tanrı olmaktan ziyade vahiy almış bir insan, ancak sıradan bir insan değil, üstün bir insan olduğunu savunmaktadır. Paulus'un, Malchion'la giriştiği tartışmada, kendisini sorgulaması için çağrılan Malchion'a da sorular sorduğunu yine bize ulaşan fragmanlardan biliyoruz. Yine bir başka fragmana göre Paulus, Logos (Söz) ile Hz. İsa'nın bileşik bir bedene sahip olamayacağı görüşünü devam ettirir:

Paulus: Söz' ün statüsünü kaybetmeden bileşik olması mümkün değildir.

Malchion: Söz ve bedeni bileşik değil mi?

Paulus: Hiç bir surette Söz ve bedeni ne bileşik olabilirler ne de karışık.

Malchion: Sayet kompozit (bileşik) tabiatı kabul etmek istemiyorsanız, Tanrı'nın Oğlu'nun, kendi bedeniylc esas itibarıyle birleşiktir demekten sakındığınız içindir. ${ }^{57}$

${ }^{53}$ Sinod sonrası yazılan mektup tartışmanın zabıtlarını da dâhil edecek fizikî imkânlara sahipti, çünkü tartışmanın zabıtlanı katipler tarafından tutulmuşıu. Eusebius HE. VII.29.2; Jerome. Lives of Illustrious Men 71.

\$4 Meselâ, kısa sürc sonra Alexandria'da Alexander ile Arius arasında tartışma başladığı zaman. Alexander yazdığ 1 mektuplarda Arius'un teolojisini reddeden uzun argümanlar geliştirmektedir. Alexander'ın mektubu için bkz. Theodoret, $H E$. I.4; Opitz, Urkunde $14 \mathrm{~s}$. 19-28.

is Paulus'un tcolojisine ilişkin ilk fragmanlar 1917-18'de yayınlandı. Bk7.. H.J. Lawlor, "The Sayings of Paul of Samosata". The Journal of Theological Studies (eski seri) 19. 1917-18: $20-45$ ve s. $115-120$.

${ }^{50} \mathrm{H}$. de Riedmatten, Les actes du procès de Paul de Samosate. (Freibourg en Suisse 1952). s.153, fragman 25 'den İngilizceye çeviri için bkz. J. Stevenson. A New Eusebius. (Londra 1987), s.261; bu fragmanların sahihliği hâlen sorgulanmaktadır meselâ bkz. A. Grillmeier, Christ in Christian Tradition (ungilizce çev. J.S. Bowden). (Londra 1965) s.177-78.

${ }^{57}$ Riedmatten, fragman 22 'den çeviri için bkz. D.S. Wallace-Hadrill. Christian Antioch. A Study of early Christian Thought in the East, (Londra 1982), s. 74. 
Paulus'un teolojisine ilişkin son olarak eklememiz gereken bir nokta, Poitiers (Fransa'da) Piskoposu Hilarius ve Salamis Piskoposu Epiphanius gibi yazarların ifade ettiğine göre, daha sonraları Nicaea Konsili sırasında Ortodoksluğun denek taşı olarak kabul edilen homoousios terimi, Paulus tarafından $\mathrm{Hz}$. İsa'nın Baba Tanrıyla ilişkisini açıklamak için kullanılmış; ancak konsil bu terimi kutsal metinlerde yeralmadığı ve Ortodoks olmadığı gerekcesiyle reddetmişti. ${ }^{58}$

Antiochia piskoposluğu, İmparator Aurelianus'un yardımı ile Paulus'un rakiplerine geçince, Paulus ve taraftarları farklı grup oluşturmuşlardır. Nicaea Konsili zamanında (m.s.325) Paulus'un izleyicileri Antiochia kilisesi çevresinde hâlâ önemli bir etkiye sahipti, çünkü konsil, Paulus taraftarlarının vaftizini kabul etmeyen ve Paulusçuların yeniden vaftiz edilmelerini belirten karar almıştır. ${ }^{59}$ Paulus'un $\mathrm{Hz}$. İsa'nın beşer yönüne vurgu yapan teolojisi çok farklı bir şekilde V. yüzyılda yeniden ciddî bir tartışma konusu olacaktır. Bu tartışmanın tarafları, Antiochia kökenli İstanbul Piskoposu Nestorius ile Alexandria Piskoposu Cyrillus'dur ${ }^{60}$ Tartışmanın konusu ise $\mathrm{Hz}$ Meryem'in Tanrı $\mathrm{m} ı$ yoksa çocuk mu doğurduğudur. Bu tartışma 'Tanrı doğuran' anlamına gelen Theotokos tartışması olarak da bilinir. ${ }^{61}$ Theotokos tartışmasında Nestorius'un kaleminden çıkan metinlerde Paulus'un adı geçmemekle beraber, Hz. Meryem'in Tanrı değil, çocuk doğurduğunu ve bu çocuğun daha sonra Tanrılaştığı şeklindeki Nestorius teolojisindeki Paulus'un izlerini görmek mümkündür ${ }^{62}$

Doğu kiliselerinde, $\mathrm{Hz}$. İsa'nın tabiatındaki ilâhî boyut üzerine tartışmalar üçüncü yüzyılda gerçekten çok yaygın idi. Nitekim önceleri Alexandria kilisesine mensup olan fakat daha sonra politik nedenlerden dolayı bu kentten sürülen ve Filistin Caesarea'sına yerleşen Origenes'in, Roma İmparatorluğu'nun doğu kentlerinde monarkhia teolojisini savunanlara karşı giriştiği mücadele bu olguya işaret etmektedir. Origenes'in Arabia'da (Ürdün) ve Mısır'lı Heracleides isimli bir piskoposla yaptığı

\footnotetext{
${ }^{58}$ Hilary of Poiteres, De Synodis, 81; Epiphanius, Panarion 69; homoousios teriminin tarihi için bkz. J.N.D. Kelly, Early Christian Creeds, (Londra 1972), s. 242-54; Hanson, a.g.e. s.190-202 ve 436-46.

${ }^{59}$ Bkz. yukarida not 48 .

(t) Cyrillus'un teolojisi daha sonra Mısır Kıpti kilisesinin temcli hâlinc gclecektir. Bu konuda en önemli monograf için bkz. W.F.C. Frend. The Monophysite Church (Cambridge 1979); ayrica bkz. R. Wilken, "Monophysitism" Fcrguson, a.g.e (içinde) s. 776-78; ancak Monofizit teoloji ö7gün kimliğine 451 'deki Kadıköy konsilinden sonra kavuşacaktır.

"' 429'da çıkan bu tartışma 431 'de toplanan üçüncü ekümenik Efes Konsili'nde reddedilir ve Nestorius azledilerek sürgüne gönderilir. Olayların çağdaşı Socrates'in kilise tarihi bu bakımdan çok değerlidir. Bkz. Socrates. HE. VII.29; VII. 32.

12 Socrates. $H E$. VIl.32.6'da Nestorius'u Pauluş̧u bir teolojiye sahip olmakla itham ederken ikj- üç satır ileride (VIl.32.9) yine de tam olarak ona Paulusçu denemeyeceğini belirtiyor. Nestorius'un teolojisi için bkz. Kelly. Early Christian Doctrines, s. 310 vd.
} 
tartışmalar, monarkhia teolojisine olan eğilimlere işaret etmektedir ${ }^{63}$ Keza aynı Origenes Bostra (bugün Ürdün'de) piskoposu Beryllus ile monarkhia teolojisi üzerine tartışmış ve onu yeniden Ortodoksluğa döndürmüştür. ${ }^{64}$ Eusebius, Origenes'in monarkhia teolojisi taraftarı Hristiyanlara karşı daha bir dizi tartışmalarından bahsetmektedir. ${ }^{6.5}$

\section{Aryanizm ve Nicaea Çözümü}

IV. yüzyıl, Erken Hristiyanlık tarihinin belki de en uzun asrıdır. Bunun en önemli sebeblerinden biri, Diocletianus'un (284-305) 303'de başlattığ şiddetli takibatın hemen akabinde Constantinus'un beklenmedik bir şekilde Hristiyanlığı yasal dinlerden biri hâline getirmesidir. ${ }^{60}$ Bir başka sebeb ise, Alexandria'da patlak veren bir tartışmanın neredeyse bütün IV. yüzyıl boyunca Roma dünyasını geniş ölçekte meşgul etmesidir. Aryanist tartı̧̧ma olarak bilinen bu politik ve teolojik kamplaşma ilk defa MS. 318 ile 320/1 tarihleri arasında Alexandria'da ortaya çıkmıştır. ${ }^{67}$ Aryanizm modern literatürde çok canlı bir şekilde tartışılmış ve hâlen de tartışılmakta olan bir konudur, dolayısıyla, Hristiyan heretiklik tarihi içerisinde en çok ilgi gören konuların başında gelir. ${ }^{68}$ Aryanist tartışma nasıl başlamışıtı? Hem Arius'a hem de Piskopos Alexander'a ortak bir mektup yazarak kilise barışını temin etmeye çalışan İmparator Constantinus'a göre tartışmanın kaynağı Piskopos Alexander' $n$ otoriteryen girişimleriydi. ${ }^{69}$ Aryanist tartışmayı elbette sadece İmparatorun yazdığı gibi Piskopos Alexander'ın otoriteryen eğilimleri ile açıklayamayız; ancak bu politik tutumun kaynayan bir teolojik tartışmanın

${ }^{63}$ Origen, Dialogue with Heracleides.

${ }^{64}$ Eusebius, $H E$, VI.33.1-4

is Eusebius, $H E$, VI.23.4

* Constantinus'un 313'de Licinius ile birlikte yayınladıklanı Milano fermanı, Hristiyalığı yasal dinlerden birisi hâline getirmektedir. Ferman için bkz. Lactantius, On the Deaths of the Persecutors, 48.2.12; Constantinus, Milano fermanından sonra, Hıristiyanlığı gözdc bir din hâline getirmek için de bazı girişimlerde bulunmuştur. Meselâ. devlet veya özel kişilerce müsadere edilen kilise mülkünü restore ettiği gibi, kendisi de kiliseye yüklü miktarlarda bă̆ış yapmıştır. Eusebius, $H E, X .5 .15-17$ ve X.6.

67 Aryanistliğın ilk çıkış kronolojisi tartışmalıdır. 318'den 323'e kadar değişik tarihler önerilmektedir. Bk7. W. Telfer, "When Did The Arian Controversy Begin?" JThS 47. 1946: 129-142: H-G. Opitz, "Dic Zcitfolgc des arianischen Streites von den Anfängen bis zum Jahrc 328" Zeitschrift für Neu Testamentliche Wissenschaft 33, 1934: 131-159.

${ }^{*}$ XX. Yüzyılın başında H.M. Gwatkin, Studies of Arianism (Londra 1900), ile başlayan Aryanizm üzcrine araştırmalar seksenli yıllarda çok önemli ürünler vermiştir. Mesela bkz. R. Williams, Tradition of Heresy: Arius, (Londra 1987), Hanson 1988, Aryanizm üzerine en hacimli monografidir. M. Wiles, Archetypal Heresy, Arianism through the Centuries. (Oxford 1996), Aryanistliğin tarihî seyri için önemli bir eserdir.

* Constantinus'un mektubunun tam metni için bkz. Eusebius, VC II.64 vd Alexandria'da o 7.aman dokuz farklı kilise mevcuttu ve bunlardan Baucalis kilisesinin papazı olan Arius -ve tabi diğerleri de-piskopostan bağımsız olarak vaaz edebiliyorlardı. Dolayısıyla piskopos burada kiliscleri kendi kontrolü altına toplamaya çaiışıordu. 
su yüzüne çıkmasında önemli bir pay sahibi olduğu da kesindir. Kilise tarihçisi Socrates'e göre ise bu tartı̧̧ma, Arius'un, piskoposu Alexander'ın kilisede $\mathrm{Hz}$. İsa ile Baba Tanrı ilişkisini açıklarken her ikisinin de aynı eşitlikte ve $\mathrm{Hz}$. İsa'nın, Baba ile aynı özden (homoousios) olduğunu söylemesine (yani her zaman Tanrı her zaman Oğul) sesli tepki göstermesiyle başlamıştır. ${ }^{70} \mathrm{Bu}$ noktadan itibaren, Alexandria kilisesinde Arius'u yeniden kiliseye entegre etmek için yapılan görüşmeler sonuç vermemiş ve nihai olarak yüz civarında Misırlı piskoposun katılımıyla toplanan bir sinod Arius'u aforoz etmi̧ ve kaba güç kullanarak kentten sürmüştür. ${ }^{71}$ Arius buradan önce Filistin'e oradan da Nicomedia'ya gitmiştir. ${ }^{72}$ Arius'un, Roma İmparatorluğu'nun doğu kanadındaki Augustusu Licinius'un baş,kentinde eski arkadaşı Piskopos Eusebius tarafından korunması, Nicomedia-Alexandria arasında bir bildiri savaşının çıkışına yol açmıştır. ${ }^{73}$ İmparator Constantinus'un bu tartışmaya katılması, ancak onun bütün Roma dünyasının tek hâkimi olduğu 324 yılında olmuştur. Kuzey Afrika'da çıkan Donatusçu krizin şokuna rağmen, İmparator bu teolojik tartışmaya da önce arabulucu olarak girmiştir. ${ }^{74}$ Constantinus'un topladığı 325 yılındaki Nicaea Konsili, ikiyüzden fazla piskoposu bu kente çekmiş ve ilk genel konsil olarak adlandırılan bu toplantı, Arius'un teolojisini reddederek onun ve yakın destekçilerinin İmparator tarafından sürgüne gönderilmesiyle sonuçlanmıştır. ${ }^{75}$

Sonuçları sadece dördüncü yüzyılda değil fakat çok daha sonraki çağlara kadar ulaşan bu tartı̧̧manın teolojik boyutu neydi? Arius'un önce Nicomedia Piskoposu Eusebius'a ve daha sonra Nicomedia'dan, Alexandria

${ }^{70}$ Socrates, $H E, 1.5$.

"Arius. Nicomedia piskoposu Euscbius'a yazdığı mcktupta Alexandria'dan kovulmasımı şikayet eder. Arius'un mektubunun metni için bk7. Theodoret, $H E$, 1.4.1-4; Epiphanius, Panarion, 69.6; Opitz, Urkunde 1 s.1-3.

${ }^{72}$ W. Telfer, "Arius Takes Refuge at Nicomedia" Journal of Theological Studies 37, 1936: 60-3.

${ }^{73}$ Epiphanius Panarion 69'da Alexandria piskoposunun yetmiş civarında mektup yazdığını ifade eder ki. Filistin Cacsarea piskoposu Euscbius ile adaşı Nicomedia piskoposu Euscbius'un da bu bildiri savaşında etkin olduklarını biliyoruz. Bkz. Theodoret, $H E$, I.5; Opitz, Urkunde 2.3,7-10.

${ }^{74}$ İmparator, kilise işlerinden sorumlu danışmanı olan Kurtuba Piskoposu Ossius'u, Arius ve Alexander'a ortak yazdiğı bir mektupla Alexandria'ya gönderir. Ossius burada Alexander'ın safında yeralır ve Arius'a karşı açılan cephe güçlenmiş olur. Mektubun metni için bkz. Eusebius, VC, II.64-72; Ossius'un Alcxandria'deki faaliyetleri için bkz. T.D. Barnes, Constantine and Eusebius (Massachusetts \& Londra 1981) s. 212-14; C. Luibheid, The Council of Nicuea (Galway 1982), s. 14-17.

${ }^{75}$ Socrates, $H E, 1.9 .1-14$; Theodoret, $H E$, I.6; Barnes, a.g.e. s.208-223; Luibheid a.g.e. s.67 vd; R. Lane Fox. Pagans and Christians in the Mediterrenean World from the Second Century AD. to the Conversion of Constantine, (Harmondsworth 1986) s. 654-56, 663-64 
Piskoposu Alexander'a yazdı̆̆ mektuplardan ve şiir formundaki bir başka derlemesinden, teolojik fikirlerini kısmen de olsa bulabiliyoruz. ${ }^{76}$

Hristiyan itikadını oluşturan iki temel unsur Baba Tanrı'nın ve $O \breve{g} u l$ 'un tanımlanması sorunu bu tartışmanın teolojik özünü oluşturuyordu. Arius'un temel vurgusu, Baba Tanri'nın birliği (monas) mutlaklığı, ululuğu, yaratıcılığı, emsalsizliği, eşsizliği ve kesin yüceliği üzerinedir. $B a b a$ 'nın başlangıcı yoktu fakat $O \breve{g} u l$ bir başlangıca sahipti. $O \breve{g} u l, B a b a$ 'ya tabiiydi ve $O$ 'nun tarafından yaratılmıştı. Fakat $O \breve{g} u l$ yaratıklar içinde en mükemmel olanı idi. ${ }^{77}$ Arius, Thalia adlı eserinde, Katolik Kilisenin benimsediği manada olmamakla beraber, Teslis'i kabul etmekte fakat arada bir hiyerarşi olduğunu, Baba Tanri'nın en yüce varlık olarak Oğul'u atadığını yazmaktadır ${ }^{78}$ Ŏgul belli bir başlangıca sahip olduğu hâlde Baba Tanrt başlangıcı ve sonu olmayan olarak anılmaktadır. İlk Aryanist kuşakta bu teoloji tamamen aynıdır. Nicomedia Piskoposu Eusebius, Tyrus'lu (Fenike/eski Suriye) meslekdaşı Paulinus'a yazdığı mektupta, ne iki başlangıçsız varlık olduğunu ne de var olan Bir'in bölündügünü halbuki Ŏgul'un yaratıldı̆̆ını ve evlat edinildiğini, Kutsal Metinlerden böyle ögrendiklerini yazmaktadır. ${ }^{79}$ Arius, Thalia'sında da Baba Tanri'nın mutlaklığı, benzersizliği ve eşsizliği üzerinde durmakta ve $O \breve{g} u l$ 'un ona tâbi olduğunu kendi kendine var olmayıp Baba Tanrt sayesinde vücud bulduğunu söylemektedir. ${ }^{80}$

Arius'tan yarım asır evvel Antiochia Piskoposu Samsatlı Paulus'da, $O \breve{g} u l ' u, H z$. Meryem'den olma bir beşer olarak kabul ediyordu ${ }^{81}$. Hristiyan heresizmini tasnif eden altıncı yüzyıllı tarihçi Arbaya'lı Bardessebba, Arius'u Samsatlı Paulus ile aynı çizgiye yerleştirdiği hâlde, ${ }^{82}$ Arius, Paulus'un mirasını sahiplenmemektedir. Bunun en önemli sebebi muhtemelen $\mathrm{Hz}$. İsa ile Baba Tanrı'nın ilişkisini açıklarken, Arius'un ve Paulus'un farkh anahtar terim kullanmalarıdır. Yukarıda ifade edildiği gibi, Paulus bu ilişkiyi açıklarken homoousios (=aynı öz) terimini kullanmış ve bu terim dönemin ortodoksluğuna ters düştügü için reddedilmişti. Arius ve arkadaşları ise, Baba Tanrı ile $\mathrm{Hz}$. İsa ilişkisini homoiosios (=benzer öz) terimi ile açıklama eğilimindeydi. Nicaea Konsili nde her iki terim de

${ }^{76}$ Aryanist teoloji tartışmasının ilk çıktığı dönemlerdeki Arius'un mektupları ve Thalia için bkL. Theodoret, HE. 1.4.1-4; Epiphanius, Panarion, 69.6; Opitz. Urkunde 1, s.1-3; Athanasius. On the Synods of Ariminum and Seleucia, 15 ve 16; Epiphanius. Panarion, 69.7; Arius 'un İmparatora gönderdiği mektup için bkz. Opitz. Urkunde 30 s. 64.

$\pi$ Arius bu noktada Samsatlı Paulus ile birleşiyor çünkü o da Hz. İsa'yı beşer ancak en mükemmel olanı diye niteliyordu. Yukarıda Paulusla ilgili bölümü karşılaş̧ırınız.

${ }^{78}$ Arius'un bu eseri için bkz. Athanasius, On the Synods of Ariminum and Seleucia, 15.

n) Euscbius'un mektubu için bkz. Theodoret, $H E$, I.5.

* Arius'un Thalia'sı onun amansız düşmanı Athanasiusun yazıları arasındadır. Athanasius, On the Synods, 15.

${ }^{81}$ J. Stevenson, a.g.e s.261.

${ }^{82}$ Wallace-Hadrill, a.g.c s. 67. 
gündeme gelmiş, Aryanist grubun homooios terimini kabul edilebilir bulması üzerine, bu terim Alexandria piskoposunun önderliğindeki grup tarafından özellikle gündem dışına atılmış ve Aryanistlerin kabul edemeyecekleri homoousios terimi benimsenmişti. ${ }^{8.3}$

Aryanizm Nicaea'da reddedildi ama orada benimsenen itikad metni özellikle Doğu'da kimseyi mutlu etmedi. Nicaea'da aforoz edilerek Constantinus'un askerleri tarafından sürgüne gönderilen Arius ve arkadaşları, yine Constantinus devri kilise toplantılarında aforozu kaldırılarak tekrar kiliseye kabul edilmiştir ${ }^{84}$ Dahası Constantinus'u ölüm döşeğinde vaftiz eden, Nicaea Konsili'nde sürgüne gönderdiği, Aryanizmin ünlü hamisi Nicomedia Piskoposu Eusebius olacaktır ${ }^{85}$ Nicaea Konsili'nin hazırladığı itikad metni, Constantinus'un hayatı boyunca hiç bir surette tartışma konusu yapılmadı veya onun yerini alacak bir başka itikad metni üretilmedi, ancak Constantinus'un ölümünden sonra Roma İmparatorluğu'nun doğu kanadının Augustusu olan II. Constantius (337-61), Aryanist felsefeye sempatikti. İmparatorun bu felsefî sempatisinin siyasal bir temeli de vardı: Suriye'den Tuna boylarına kadar önde gelen büyük kentler Aryanist piskoposların kontrolündeydi. Bir başka mühim faktör, babasının sağlığında doğuda Caesar olan Constantius, Nicaea itikadının Roma İmparatorluğu'nun doğu eyaletlerinde konsensusu sağlayamadığını görmüş olmalıdır. Netice olarak, Constantius, Aryanizmi ya da kabul edilebilir bir itikat metnine ulaşanilmek için iktidarı süresince sayıları 10'u bulan itikad metni yazılmasına imkân sağladı.

$337^{\prime}$ den $357^{\prime}$ ye kadar yirmi yıllık sürede Hristiyan piskoposlar çeşitli vesilelerle toplanarak kabul edilebilir bir inanç formülü bulmaya çalıştılar. ${ }^{86}$ 341 'de Antiochia'da 343'te Serdica (bugün Sofya) ve Philippopolis'te (Plovdiv, Bulgaristan) 344'te yine Antiochia'da itikad metinleri ürettiler. Fakat esas çatlak ve Aryanizmin radikal yorumu 357'de toplanan Sirmium Konsili'nde geldi. Sirmium Konsili'nin ortaya koyduğu itikad metni (amentü), Hz. İsa'nın tabiatının Baba Tanrı ile aynı olmadığını ve Yuhanna Incili'nde yeralan (14:28) "Beni gönderen Baba (Tanrı) benden daha büyüktür" ayetine dayanarak, O'nun [Hz. İsa'nın] tamamen Baba'ya tâbi olduğunu savunuyordu. ${ }^{87}$

\footnotetext{
${ }^{83}$ Athanasius, Defence of the Nicene Definition, 19-20.

*: Socrates, $H E$, I.25, 33: Sozomenus, $H E$. I.21, II.16. 27; dönemin kilise politikalan için ayrica bkz. Barnes, a.g.c. s. 224-44; Hanson, a.g.e. s. 172-78.

${ }^{35}$ Eusebius, VC. 61 .

Bu dönem, Hanson tarafından tamamen bir semantik kargaşa dönemi olarak adlandırılır. Devrin itikad metinleri ve bunların tarihsel arka planı için bkz. Hanson a.g.e s. s.181 vd. Kelly, Creeds, s. 263-95;

${ }^{87}$ Yuhanna İncilinin pek çok yerinde $\mathrm{Hz}$. İsa ya atfedilen ifadelerde çoğunlukla Baba Tanrı İsa'yı gönderen. ona güç veren onu yönlendiren olarak ortaya çıkar. Meselâ bkz. Yuhanna $3: 34-5,5: 24-27,12: 49-50,14: 15-17,31$.
} 
$\mathrm{Bu}$ arada, 336'da İstanbul'da kiliseye yeniden entegrasyonu sağlamak üzereyken ölen Arius'un adı, artık tartışmanın ismi olmaktan da çıktı. Nicaea itikadını savunmayan ve Aryanist teolojiye yakın duran piskoposlar, hiyerarşik kaygılardan dolayı Aryanist olarak anılmayı reddettiler; çünkü Arius bir papazdı ve nasıl olur da piskoposlar bir papazın izleyicisi olabilirdi? Ancak bu piskoposlar II. Constantius devrinin (337-361) hiç bir kilise toplantısında Arius'un aforoz edilmesini kabul etmemişlerdir, hatta Arius'un aforozu teklif edildiği zaman, bu teklif kilise konsillerinde bölünme sebebi hâline gelmiştir. ${ }^{88}$

Aryanizm veya onun sonraki yorumları, II. Constantius'un iktidarından, Roma İmparatorluğu'nun doğu kanadına Augustus olarak atanan Theodosius'a kadar (379-395) neredeyse Roma Hıristiyanlığının resmî itikadı oldu. ${ }^{89}$ Ancak özellikle ikinci genel (ekümenik) İstanbul Konsiliyle (381) birlikte, Aryanistler Roma İmparatorluğu içerisinde meşru konumlarını kaybettiler, çünkü Theodosius Aryanistlerin -veya diğer farklı Hristiyan gruplảrın- bütün kiliseleri Katoliklere devretmeleri konusunda ferman yayınladı. ${ }^{* 0}$ Ancak Aryanizm, Roma dünyası dışında, Gotların resmî mezhebi oldu, çünkü Gotlar dördüncü yüzyılın ortalarında Aryanist piskoposların gayretleriyle Hristiyan olmuşlardı. Aryanizm felsefî olarak batı dünyasında varolmaya devam etmiştir, hatta ünlii fizikçi Newton'un, Aryanistliği eskiçağın sahih Hristiyanlığı olarak kabul ettiği bilinmektedir. ${ }^{91}$

\section{Epilogue}

Bu çalışmanın daha başlangıcında Alexandria piskoposunun, Arius'u erken Hristiyanlıktaki teslisçi olmayan bir akımın son halkası olarak sunmaya çalıştığını ifade etmiştik. Ebioniteler'den Arius'a uzanan çizgide bir takım ortak noktalar olmakla birlikte, bunları tamamen bir gelenek zincirine yerleştirmek çok kolay değil. Bu her şeyden önce -daha evvel de

8* Antiochia konsilinde (341) piskoposlar Aryanist olarak anılmayı reddetmelerine karşın, Milano (355) ve Ariminum'da (359) Arius'u aforoz etmeyi de kabul etmediler. Athanasius, On the Synods of Ariminum and Seleucia, 6 ve 22. Theodoret, HE, II.15, Aryanist tartışma sürecinde Arius'a değişsen yaklaşımlar için bkz. M. Wiles, "Attitudes to Arius in the Arian Controversy" Arianism After Arius, Essays on the Development of the Fourth Century Trinitarian Conflicts, (ed. by M.R. Barnes \& D.H. Williams) [içinde], (Edinburgh 1993) s. 31-43; bu konsillerin tarihi için ayrica bkz. H.C. Brennecke. Hilarius von Poitiers und Die Bischofsopposition gegen Konstamius II. Untersuchungen zur dritten Phase des arianischen Streites (337-61), (Berlin 1984) s. 3-16, 164-77; T.D. Barnes, Athanasius and Constantius, Theology and Politics in the Constantinian Empire, (Cambridge \& Londra 1993) s. 109-120.144-51.

${ }^{8 y}$ II. Constantius devri kilise politikaları için bkz. Barnes, Athanasius and Constantius; R. Klcin, Constantius // und Christliche Kirche (Darmstadt 1977) s. 29-68.

* C.Th. XVI.1.2. (=Codex Theodosianus, Ing. çev. Clyde Parr, The Theodosian Code, (Princeton 1952).

"Newton'un gizli Aryanistliği ve bu teolojiyc ilişkin görüşlerinin değerlendirmesi için bkz. Wiles. a.g.e.s. $77-93$ 
ifade edildiği gibi- bu alternatif Hristiyanların yazılarının tam olarak bize ulaşmamasından kaynaklanmaktadır. I. ve II. yüzyıllardaki Ebionite ve Elkesaiteler gibi grupları diğer Hristiyanlardan ayıran, sadece $\mathrm{Hz}$. İsa hakkındaki farklı yaklaşımları, yani Hz. İsa'yı, İbrahimî gelenekteki peygamber halkası içerisinde görmeleri değil, ama aynı zamanda ibadet uygulamasındaki farklılıklarıydı (son akşam yemeği töreninde su kullanmak gibi). III. ve IV. yüzyıllardaki tartışmaların içerisinde ibadet uygulamalarını görmüyoruz ve sorun sadece $\mathrm{Hz}$. Issa'nın veya Baba Tanrı'nın konumunda dügümleniyor. Samsatlı Paulus ile Aryanistler farklı anahtar terim ile düşüncelerini ifade etmelerine rağmen, $\mathrm{Hz}$. İsa'nın sonradan yaratılması ve Baba Tanrı'ya tâbi olması noktasında aynı kategori içerisinde yeralıyorlar. Paulus ve Arius ayrıca kendi dönemlerinin kilise konsillerinde reddedilmişlerdir; ancak Arius daha sonra Nicomedia ve Kudüs konsillerinde yeniden kiliseye geri kabul edilecektir. Ebioniteler'den Paulus'a kadar ulaşan süreçte $\mathrm{Hz}$. İsa hep beşer olarak anılıyor ve ilâhî vasıflar kendisine Baba Tanrı tarafından bahşediliyor. Arius ise Baba Tanrı'nın mutlaklığına özellikle vurgu yapıyor ki, bu tutum $\mathrm{Hz}$. İsa'yı ikincil konuma yerleştiriyor. İsa teolojisi (kristoloji) konusunda, bu grup veya kişiler, mevcut kayıtlara göre biribirlerine çok yakın noktalarda birleşmelerine rağmen, hiç birisi kendinden öncekilere grup devamlılığı (tarikat zinciri gibi) anlamında bağlanamıyor. Ancak bu durum politik bir tutum olarak da değerlendirilebilir, çünkü Grek bir çevrede piskopos olan Paulus'un, kendisinden çok önceleri 'Yahudi kökenli Hristiyanlık' olarak damgalanmış olan Ebioniteler'den bilinçli olarak kendisini soyutladığı düşünülebilir. Öbür yandan Arius'un da kendisinden yarım asır önce bir sinodda aforoz edilmiş Paulus'u sahiplenmesi de düşünülemez, çünkü bu durum devrin kilise liderlerinden destek görmeyecektir.

$\mathrm{Hz}$. İsa'yı beşer olarak savunan Hristiyanların aralarından organik bir bağ kurulamaması hükmü, bunların fikirleri ve yazıları hakkında çok sınırlı bilgiye sahip olmamız dolayısıyla tartışmalı olabilir. Ancak şunu eklemekte yarar vardır: Erken Hristiyanları sadece teslisçi ve anti-teslisçi (veya Tek Tanrıc1) olarak tasnif etmek çok doğru değildir, çünkü kendilerini Hristiyan olarak niteleyen başka gruplar -bunlar da ana kilise dışında kalmaktadırlarteoloji olarak hem kiliseye hem de Ebioniteler'den Arius'a uzanan çizgideki tek tanrıcı teolojiye aynı oranda uzaktırlar.

\section{Antik Kaynaklar ${ }^{92}$}

[Kısaltmalar: a.g.e. adı geçen eser; $\mathrm{ANF}=$ Ante Nicene Fathers; ANRW= Aufstieg Und Niedergang Der Römischen Welt; bkz. bakınız; HE= Historia Eccleisastica (Eusebius, Socrates, Sozomenus, Theodoret gibi antik dönem Hıristiyan yazarların kilise tarihleri için kullanılan geleneksel

92 Konuya iliş̧in modern araştırmalar dipnotlarda tam olarak yazıldı̨̆ından, tekrara kaçmamak için buraya dâhil edilmemiştir. 
kısaltma); karş. Karşılaştırınız; NPNF=Nicene and Post Nicene Fathers; Eusebius, VC, (=Vita Constantini, Eusebius'un Constantinus biyografisinin geleneksel kısaltması). Metin içerisinde isimler Latince olarak yazılmıştır.]

Athanasius, Selected Works and Letters, NPNF 2. Seri IV. Cilt, (Edinburgh 1991).

Cyprian [Cyprianus], The Letters and Treatises, ANF V. cilt, (Edinburgh 1995).

Epiphanius, The Panarion, selected passages, (İng. çev. ve edisyon P. R. Amidon) (Oxford 1990).

Eusebius, Church History \& Life of Constantine, NPNF 2 seri, I. cilt, (Edinburgh 1991). 1995)

Hilary [Hilarius], Select Works, NPNF 2. Seri, IX. Cilt, (Edinburgh

Hippolytus, The Refutation of All Heresies, \& Against The Heresy of One Noetus, ANF, V. cilt, (Edinburgh 1995).

Ignatius, Epistles, ANF I. cilt, (Edinburgh.1993).

Irenaeus, Against Heresies, ANF I. cilt, (Edinburgh.1993).

Jerome [Eusebius Hieronymus], Lives of Illustrious Men, NPNF 2. Seri, III. cilt, (Edinburgh 1996).

Justin [Iustinus], Dialogue with Trypho, A Jew, ANF I. cilt, (Edinburgh.1993).

Lactantius, On the Deaths of the Persecutors, ANF VII. cilt, (Edinburgh 1994).

Optatus, Against the Donatists, (İng. çev. M. Edwards) (Translated Texts for Historians XXVII. cilt) (Liverpool 1997).

Origen, "Dialogue with Heracleides", Alexandrian Christianity, Selected Translations of Clement and Origen (Introductions and Notes by J.E.L. Oulton and H. Chadwick) (London 1954). (Edinburgh 1994).

...-..., Against Celsus \& On the Principles, ANF IV. Cilt, Socrates and Sozomenus, Church Histories, NPNF 2. Seri II. cilt (Edinburgh 1989).

Tertullian [Tertullianus], Works, ANF III. \& IV. Cilt, (Edinburgh 1993).

Theodoret, The Ecclesiastical History, NPNF 2. Seri, III. cilt, (Edinburgh 1996). 